\title{
Zastosowanie fibryny w inżynierii tkankowej. Osiągnięcia i perspektywy.
}

Application of fibrin in tissue engineering. Achievements and perspectives.

Jakub Rech ${ }^{1}$, Wojciech Rogóż ${ }^{2}$, Aleksandra Borecka ${ }^{3}$, Artur Turek ${ }^{* 4}$

${ }^{1}$ Zakład Biotechnologii i Inżynierii Genetycznej, Wydział Nauk Farmaceutycznych w Sosnowcu, Śląski Uniwersytet Medyczny w Katowicach

2 Katedra i Zakład Farmacji Fizycznej, Wydział Nauk Farmaceutycznych w Sosnowcu, Śląski Uniwersytet Medyczny w Katowicach

${ }^{3}$ Centrum Materiałów Polimerowych i Weglowych, Polska Akademia Nauk, Zabrze

Abstrakt $\quad{ }^{4}$ Katedra i Zakład Biofarmacji, Wydział Nauk Farmaceutycznych w Sosnowcu, Śląski Uniwersytet Medyczny w Katowicach

W ostatnich latach istotnym obszarem zastosowania fibryny stała się inżynieria tkankowa, w której wykorzystuje się naturalne właściwości biostatyczne i bioaktywne fibryny, a także możliwość pułapkowania i wiązania w jej strukturze czynników wzrostu. Fibryna jest najczęściej stosowana w postaci żeli i dysków. Jednak każda postać wskutek pochłaniania wody docelowo przyjmuje postać żelu. Białko to w warunkach in vivo spełnia rolę rusztowania dla komórek, a także może być aplikowane w miejsca trudno dostępne - może wypełniać ubytki tkanek i podtrzymywać tkanki okalające, zapobiegając ich zapadaniu się. Ponadto fibryna hamuje krwawienie i inicjuje proces odnowy, jak również pełni rolę stymulatora wzrostu komórek. Przez modyfikacje struktury fibryny cząsteczkami adhezyjnymi, można przyspieszyć odbudowę prawidłowej struktury tkanek. Jej właściwości strukturalne mogą być także wykorzystywane jako rezerwuar czynników wzrostu i system ich przedłużonego uwalniania. Fibryna jest materiałem biodegradowalnym, umożliwiając skorelowanie ubytku matrycy fibrynowej z odbudową tkanek własnych pacjenta. Wprowadzenie metod druku 3D i elektroprzędzenia umożliwia formulację dopasowanych do uszkodzeń kształtek oraz włóknin bez utraty bioaktywnych funkcji fibryny. Metody te umożliwiają także poprawę właściwości mechanicznych przez otrzymywanie m.in. włóknin fibryny z innymi polimerami, co jest szczególnie uzasadnione w przypadku materiałów stosowanych w odbudowie takich struktur jak ścięgna czy kości. Biotechnologiczna synteza fibrynogenu może w przyszłości uniezależnić pozyskiwanie go z krwi i zwiększyć popularność wyrobów medycznych otrzymywanych z fibryny.

Słowa

fibryna $\cdot$ regeneracja tkanek • inżynieria tkankowa $\cdot$ czynniki wzrostu

Otrzymano: 25.08.2020, Zaakceptowano: 03.02.2021

Abstract

In the last years, bioactive and biostatic activities of fibrin and the ability to entrapping and binding growth factors play a significant role in tissue engineering. Fibrin is most commonly applied in forms of gels and discs. Finally, every form of fibrin becomes gel as a result of water uptake. In vivo fibrin acts as a cell scaffold and can be applied as the gel in hardly accessible areas, filling damaged tissues and supporting surrounding tissues. Moreover, fibrin stops bleeding, initiates tissue repair processes, and plays the role of a cell stimulator agent. The modification of fibrin structure with adhesive molecules accelerates the reconstruction of the normal tissue. Structural properties of fibrin also make it possible to use it as a reservoir of growth factors and a controlled growth factor release system. The biodegradability of fibrin also allows for correlation of the matrices degradation with tissue reconstruction. Fibrin processing by 3D printing and electrospinning methods makes it possible to produce tailored to the injury pieces and nonwovens without losing fibrin bioactive properties. These methods could be used for the improvement of the mechanical properties of fibrin by the formulation of nonwovens with other polymers. These durable materials are especially important for the proper healing of such structures as bone and tendons. In the future, the biotechnological methods of fibrinogen synthesis may make it independent from blood source and increase the popularity of fibrin-based medical devices.

Keywords

fibrin • tissue regeneration • tissue engineering $\bullet$ growth factors

Received: 25.08.2020, Accepted: 03.02.2021 


\section{Wstęp}

Jednym z częściej stosowanych w inżynierii tkankowej białek fibrylarnych jest fibryna powstająca z fibrynogenu (FBN) pod wpływem trombiny (TRB) [1,6]. FBN w postaci proszku stosowano w tamowaniu krwawienia ran zewnętrznych skóry i zębodołów poekstrakcyjnych [83]. Zyskał on szczególne znaczenie podczas drugiej wojny światowej w hamowaniu krwawienia [24]. Następnym krokiem było wykorzystanie FBN w tamowaniu krwawień wewnętrznych [31], czy też w terapii zastępczej niedoboru FBN [63].

Obecnie w celach terapeutycznych nie stosuje się właściwie samego FBN, tylko fibrynę otrzymaną z FBN i TRB. Proces polimeryzacji fibryny jest zoptymalizowany do warunków in vitro [51, 76].

Szerokie wykorzystywanie fibryny w inżynierii tkankowej wynika z jej naturalnych właściwości biostatycznych (tworzenie trójwymiarowego rusztowania dla komórek, podtrzymywanie tkanek) i bioaktywnych (indukcja angiogenezy, indukcja syntezy składników macierzy zewnątrzkomórkowej (ECM) i cytokin, nasilenie migracji leukocytów i proliferacji komórek). Istotnym atutem wykorzystania tego białka jako podłoża jest biozgodność fibryny i jej produktów biodegradacji. Ponadto fibryna umożliwia wypełnianie ubytków w tkankach i narządach, ich spajanie i uszczelnianie, inkorporację i pułapkowanie czynników wzrostu oraz substancji leczniczych. Co więcej, modyfikacja struktury stwarza możliwości kontrolowania degradacji, a tym samym wpływ na czas uwalniania substancji leczniczych i makromolekuł [12, 27, 48, 53, 57, 67, 77].

Właściwości fizykochemiczne i reologiczne umożliwiają formulację różnych postaci fibryny (skafoldów, kształtek) w temperaturze ciała człowieka, bez udziału rozpuszczalników organicznych i cytotoksycznych inicjatorów polimeryzacji [51, 92].

\section{Otrzymywanie fibryny}

Otrzymywanie fibryny in vitro dla potrzeb inżynierii tkankowej, opiera się na znanych procesach biochemicznych zachodzących in vivo podczas gojenia się ran, polegających na enzymatycznej transformacji rozpuszczalnych monomerów FBN (ryc. 1) do nierozpuszczalnej sieci fibryny. Zarówno in vivo jak i in vitro fibryna powstaje według tego samego mechanizmu.

Fibryna otrzymywana jest w wyniku wieloetapowej reakcji polimeryzacji FBN, ulegającego aktywacji pod wpływem hydrolitycznej aktywności TRB (ryc. 2) [59]. Pierwszym etapem powstawania sieci fibrynowej jest uwolnienie fibrynopeptydów A i B (fbpA i fbpB; ryc. 2 - I etap) pod wpływem TRB, rezultatem czego jest odsłonięcie węzłów A i B [92].

W kolejnym etapie następuje polimeryzacja aktywowanych cząsteczek FBN do liniowych protofibryli w wyniku oddziaływań między dołkami a i b oraz odsłoniętymi węzłami A i B (ryc. 2 - II etap) [92].

Następnie uwolnieniu ulegają domeny $\alpha \mathrm{C}$, które przez wzajemną komplementarność sieciują powstające protofibryle (ryc. 2 - III i IV etap) [26].

W ostatnim, najwolniejszym etapie polimeryzacji fibryny, nadawana jest ostateczna wytrzymałość formującej się sieci fibrynowej. TRB wraz z jonami wapnia aktywuje czynnik XIII kaskady krzepnięcia krwi do aktywnej formy (FXIIla), która wykazuje aktywność transglutaminazy w stosunku do określonego fragmentu peptydowego (NQEQVSPL), obecnego w niciach a i y fibryny (ryc. 1) [52]. Umożliwia to tworzenie połączeń pomiędzy łańcuchami FBN ( $\alpha-\alpha ; \alpha-\gamma$; Y-ү) z przewagą wiązań łańcuchów $Y-\gamma$ (ryc. 2 - V etap) [52].

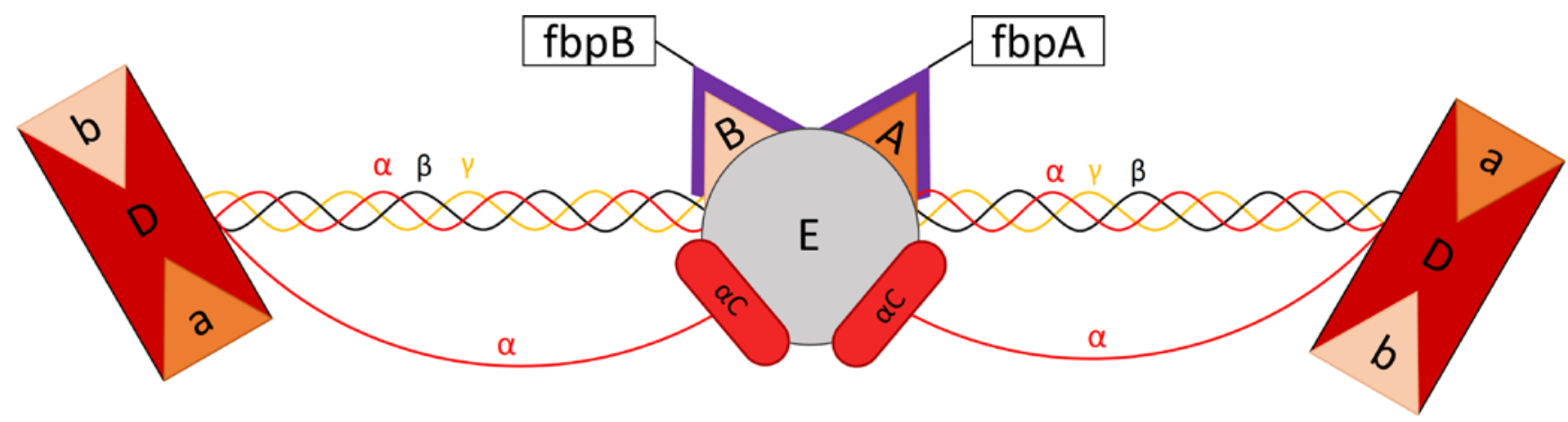

Ryc. 1. Schemat budowy FBN: a i b - dołki w domenie D fibrynogenu; A i B - węzły w domenie E fibrynogenu; D - domena dystalna fibrynogenu; $E$ - domena centralna fibrynogenu; fbpA i fbpB - fibrynopeptydy A i B; $\alpha, \beta, \gamma$ - helisy łączące domeny $E$ i $D$ fibrynogenu oznaczone liniami falowanymi; $\alpha \mathrm{C}$ - domena $\alpha \mathrm{C}$ fibrynogenu 
Prowadzenie procesu in vitro pozwala dodatkowo na regulację właściwości strukturalnych i biochemicznych białka $[17,67,85]$. W przypadku fibryny stopień usieciowania może być regulowany przez zmianę stężenia FBN i TRB. Wzrost stężenia jednego lub obu tych czynników powoduje wzrost gęstości sieci fibrynowej. Na jej zagęszczenie wpływa także wzrost stężenia fibronektyny, jednak w znacznie mniejszym stopniu [65].

\section{Metody izolacji fibrynogenu}

Do celów technologicznych fibryna otrzymywana jest z FBN pochodzenia zarówno autologicznego jak i allogenicznego [76]. Osocze autologiczne jest obecnie wykorzystywane do izolacji FBN na małą skalę [98], natomiast głównym źródłem komercyjnym FBN jest ludzkie osocze pochodzące od jednego lub wielu dawców [18]. Jednak, ze względu na ryzyko transmisji chorób wirusowych, w przypadku tego materiału prowadzone są rutynowo badania w kierunku obecności

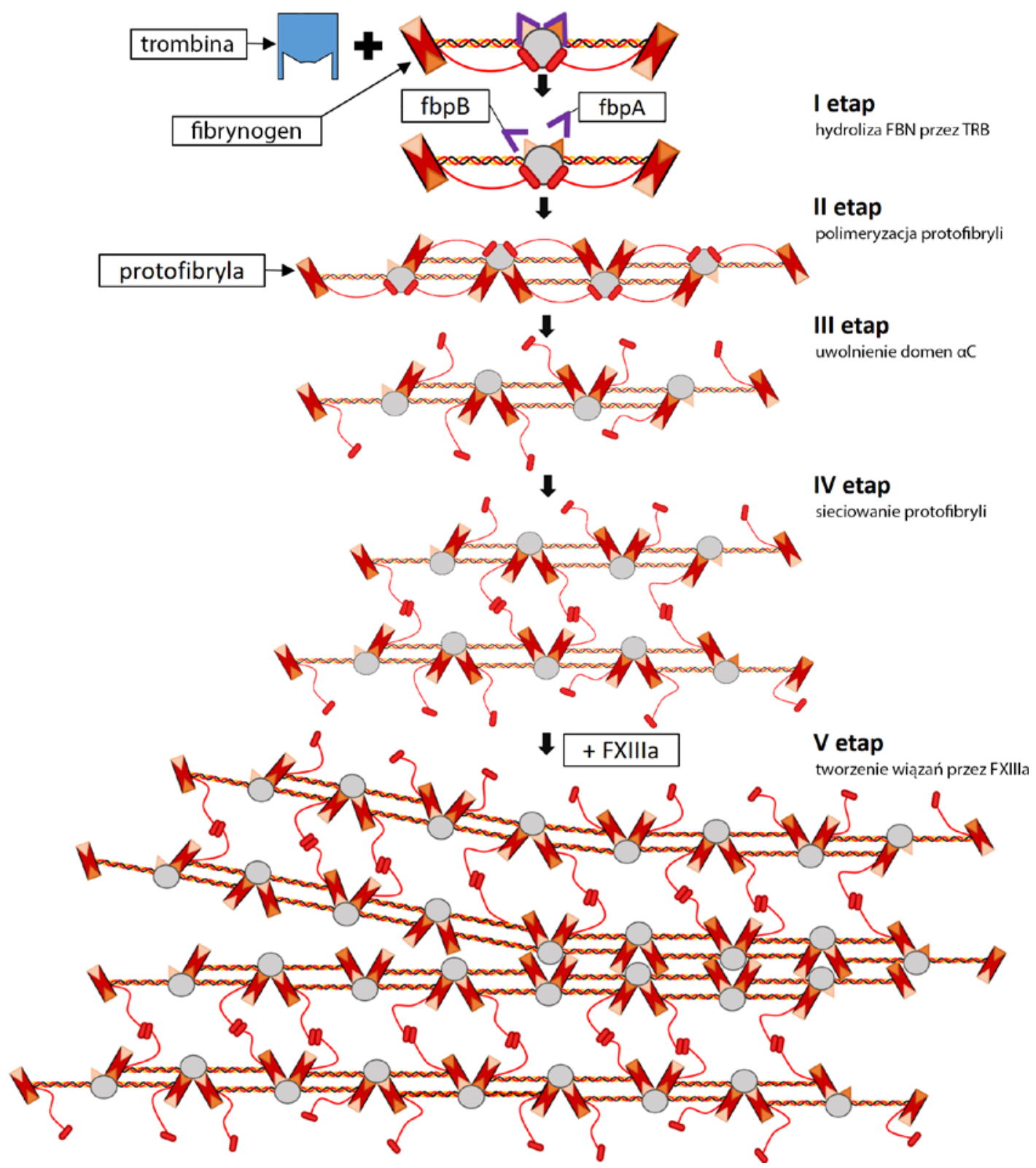

Ryc. 2. Etapy polimeryzacji cząsteczek FBN do struktury fibryny: I - hydroliza fbpA i fbpB; II - polimeryzacja monomerów FBN do protofibryli za pomocą oddziaływań węzłów A i B FBN odpowiednio z dołkami a lub b FBN; III - uwolnienie domen aC FBN; IV - sieciowanie powstałych protofibryli z udziałem domen aC FBN; V - tworzenie dodatkowych wiązań pomiędzy usieciowanymi protofibrylami z udziałem FXIIla. 
wirusów (HBV, HIV i parwowirusa B19) oraz prionów (choroba Creutzfeldta-Jakoba) [34, 39, 43]. Bezwzględnie unika się już stosowania FBN ksenogenicznego ze względu na ryzyko odpowiedzi immunologicznej [33, 79].

Najprostszą i najczęściej wykorzystywaną komercyjnie metodą izolacji FBN jest krioprecypitacja. Pozostałe metody, wymagające użycia siarczanu amonu, poli(tlenku etylenu) (PEG), etanolu oraz chromatografii powinowactwa, mają marginalne znaczenie komercyjne i są stosowane do izolacji FBN na mniejszą skalę. Wskazane metody pozwalają na uzyskanie różnego stopnia czystości produktu (42-92\%) w postaci roztworu $[18,76]$.

Zaproponowano również w pełni funkcjonalny model komórkowy umożliwiający otrzymanie rekombinowanego FBN w wysokich stężeniach. Obecnie nie ma on jednak większego znaczenia komercyjnego [36].

\section{Postaci fibryny w inżynierii tkankowej}

W inżynierii tkankowej najczęściej proponowanymi postaciami fibryny są żele, dyski, filmy i maty [40, 96, 102, 103]. Należy podkreślić, że żele przygotowywane są w większości ex tempore, natomiast pozostałe postacie stają się żelem na skutek pochłaniania wody już po wprowadzeniu do organizmu. Nazwy handlowe fibryny zarejestrowanej jako wyrób medyczny, często zawierają sposób zastosowania żelu (klej, uszczelniacz, hemostat) [33, 87].

Żele, dyski, filmy i maty są uzyskiwane różnymi metodami, wszystkie jednak zapewniają efektywne mieszanie FBN i TRB. Istotne jest, że sposób łączenia poszczególnych składników nie wpływa na strukturę fibryny. W otrzymywaniu z niej wyrobów medycznych unika się natomiast podwyższonych temperatur (powyżej $100^{\circ} \mathrm{C}$ ) i rozpuszczalników organicznych [84, 92, 94].

Najprostszym sposobem otrzymywania żelu fibrynowego jest mieszanie roztworów FBN i TRB na folii aluminiowej. Natomiast do bardziej popularnych metod należą systemy dwustrzykawkowe, zawierające osobno roztwory FBN i TRB. Stężenia obu składników są zoptymalizowane w taki sposób, aby fibryna tworzyła się na wyjściu igły dozującej [95, 96, 103].

Postać dysków i filmów otrzymuje się przez wylanie z żelu fibryny do odpowiednich form. W przypadku dysków najczęściej są to płytki wielodołkowe do hodowli komórkowych lub formy silikonowe [40, 73, 74, 104]. Natomiast maty fibrynowe w postaci włóknin uzyskuje się metodą elektroprzędzenia z wykorzystaniem systemów dwustrzykawkowych [5, 80, 96].

Istotnym rozwiązaniem jest zastosowanie druku 3D w otrzymywaniu fibryny. Metoda opiera się na stosowaniu tuszu FBN w roztworze TRB i vice versa, jak również na inkubacji wydrukowanej matrycy FBN w roztworze TRB. Sposób ten pozwala na otrzymanie fibryny w dowolnym kształcie [16, 35, 99, 100].

Poszczególne postacie mają różne zastosowanie terapeutyczne. Postać żelu umożliwia małoinwazyjną aplikację fibryny do trudno dostępnych miejsc w takich tkankach jak: nerwowa, kostna, chrzęstna i mięśniowa serca. Naprawa uszkodzonych tkanek jest wspomagana komórkami i adekwatnymi czynnikami wzrostu wprowadzonymi do żelu [12, 40, 71, 81, 95, 97, 103].

Dyski fibrynowe są stałą postacią fibryny, wykorzystywaną głównie jako rusztowanie komórkowe, uwalniające czynniki wzrostu w terapii uszkodzeń kostnych [71, 73, 74, 98, 104].

Filmy fibrynowe są stosowane $w$ formie łat w zabiegach naprawczych ubytków sercowo-naczyniowych [90], a także jako substytuty skóry [37, 101].

Maty fibrynowe otrzymane metodą elektroprzędzenia, mają bardziej optymalną strukturę wewnętrzną przy tworzeniu podłoży trójwymiarowych wykorzystywanych w zabiegach naprawczych skóry. Stosowane są również jako opatrunki w gojeniu ran i jako materiał hemostatyczny [5, 80, 96].

\section{Właściwości biostatyczne i bioaktywne rusztowań fibrynowych}

Właściwości fibryny zapewniają wiele korzyści wynikających z jej aktywności biostatycznej i bioaktywnej. Dzięki temu fibryna in vivo oprócz roli rusztowania komórkowego aktywnie wpływa na proliferację komórek.

Fibryna posiada cenne właściwości w spełnianiu roli podłoża w inżynierii tkankowej. Z jednej strony nie jest wystarczająco wytrzymała do przenoszenia dużych obciążeń, ale z drugiej strony właściwości elastyczne dają możliwość do rozciągnięcia fibryny do ponad 2-krotności początkowej długości. Polepszenie wytrzymałości osiągane jest przez łączenie fibryny z innymi materiałami, takimi jak: nanowłókna węglowe, chitozan, polikaprolakton, polilaktyd, poliglikolid, poli(laktyd-ko-glikolid) (PLGA) i PEG [3, 9, 47, 49, 78, 89].

Matryce fibrynowe posiadają trójwymiarową strukturę wewnętrzną, zapewniającą optymalne warunki do wzrostu różnych komórek, w tym dla fibroblastów, chondrocytów czy też komórek nerwowych [56, 95, 97, 104].

Fibryna jako naturalny stymulator naprawy uszkodzonej tkanki stanowi również odpowiedni dodatek do biomimetycznych rusztowań opartych na: elastynie, fibroinie, heparynie, keratynie, kolagenie i kwasie hialuronowym [14, 42, 51, 64, 66]. Wskazane rusztowania lepiej naśladują 
strukturę ECM, poprawiając szybkość odnowy uszkodzeń [66].

Klinicznie wykorzystanie fibryny skraca czas operacji oraz zmniejsza intensywność stanu zapalnego $[8,21$, 46]. Ze względu na swoje właściwości fibryna znalazła bardzo szerokie zastosowanie terapeutyczne w wielu specjalnościach zabiegowych, m.in. jako uszczelniacz ran, klej tkankowy i rusztowanie komórkowe [22, 53, 54, 79]. Fibryna skutecznie zastępuje również klasyczne szwy chirurgiczne podczas operacji gałki ocznej, rdzenia kręgowego lub przepukliny $[21,46]$.

Właściwości bioaktywne fibryny umożliwiają optymalizację leczenia uszkodzeń tkanek w istotny sposób. W strukturze fibryny występują miejsca wiążące integryny, fibronektynę, fibulinę i czynnik von Willebranda. Są to białka kluczowe w przebiegu naprawy tkanek. Ta wieloskładnikowa struktura imituje ECM i zwiększa adhezyjność komórek [32, $50,93]$. Ponadto domena wiążąca heparynę (HBD) w FBN pozwala na wiązanie czynników wzrostu z następujących rodzin:

- czynników wzrostu śródbłonka naczyń (VEGF) (VEGF-B), do której należą płytkowe (PDGF) (PDGF-AB, PDGF-BB, PDGF-DD) oraz łożyskowe czynniki wzrostu (PIGF) (PIGF-2 i PIGF-3),

- czynników wzrostu fibroblastów (FGF) (FGF-2, FGF5 i FGF-7),

- czynników wzrostu guzów $\beta$ (TGF- $\beta$ ) (TGF- $\beta 1$, TGF- $\beta 2$, BMP-2, heterodimer BMP-2/7),

- $\quad$ neurotropin (NT) (NT-3, BDNF) oraz

- białek wiążących insulinopodobne czynniki wzrostu (IGFBP) (IGFBP-5) [55].

Fibryna pełni przez to funkcję rezerwuaru wielu czynników wzrostu, wielokierunkowo przyspieszając naprawę tkanek m.in. przez nasilenie angiogenezy, hamowanie nekrozy wynikającej z niedokrwienia, nasilenia wzrostu komórek nerwowych oraz przebudowy $\mathrm{i}$ odnowy właściwej struktury tkanek [20, 56, 57, 81].

W pierwszym etapie polimeryzacji fibryny oddzieleniu ulegają fbpA i fbpB pod wpływem TRB (ryc. 2). Oba składniki pozostają jednak $\mathrm{w}$ materiale polimerowym i odgrywają ważną rolę w naprawie tkanek. Fibrynopeptydy wykazują właściwości chemotaktyczne względem fibroblastów, leukocytów, neutrofili i monocytów oraz właściwości proangiogeniczne i proproliferacyjne, przyspieszając odnowę uszkodzonej tkanki [28, 44, 68, 75]. TRB aktywuje szlaki mitogenne fibroblastów, komórek endotelialnych i mięśni naczyń krwionośnych. Uzupełnienie hodowli komórkowej o TRB może w znacznym stopniu wpłynąć na przyspieszenie proliferacji komórek [25, 29].

Stopniowa degradacja rusztowania fibrynowego stymuluje etapową naprawę tkanek gospodarza. Produkty fibrynolizy aktywują bowiem szlaki komórkowe odpowiedzialne za pobudzenie angiogenezy i syntezę składników ECM, migrację leukocytów i wydzielanie cytokin, co prowadzi do uzyskania pełnowartościowej struktury tkankowej [15, 38, 69, 77, 82]. W przypadku zbyt szybkiej degradacji proces ten można spowolnić przez inkorporacje jonów wapnia lub swoistych inhibitorów fibrynolizy, tj. aprotyniny, kwasu $\varepsilon$-aminokapronowego oraz kwasu traneksamowego do FBN lub TRB [11, 88, 91].

\section{Sposoby inkorporacji czynników wzrostu i enzymów do sieci fibrynowej}

Właściwości fibryny pozwalają na inkorporację czynników wzrostu, umożliwiając ich przedłużone i kontrolowane uwalnianie. Wydłużenie ekspozycji komórek na czynniki wzrostu zwiększa efektywność ich bioaktywnego wpływu na procesy naprawcze tkanek. Inkorporację czynników wzrostu do fibryny można osiągnąć różnymi metodami tj.:

- metodą pułapkowania w strukturze albo

- metodami wiązania niekowalencyjnego (nietrwałe) lub

- kowalencyjnego (trwałe) [57, 61, 70].

Najprostszą metodą inkorporacji czynników wzrostu do matrycy fibrynowej jest ich pułapkowanie, następujące w czasie sieciowania składników fibryny, zawierających czynniki wzrostu (ryc. $3-$ I). Nie zapewnia to jednak pełnej kontroli nad ich uwalnianiem, ponieważ czynniki wzrostu uwalniane są przez dyfuzję w stosunkowo krótkim czasie $[45,97]$. Zjawisko pułapkowania i braku pełnej kontroli nad tym procesem obserwowane jest również $w$ przypadku innych białek m.in. kolagenu [86].

Do zwiększenia kontroli nad przedłużonym uwalnianiem czynników wzrostu, stosuje się fibrynę, z którą czynniki wzrostu są związane za pomocą łączników, które to łączą się z fibryną wiązaniami niekowalencyjnymi lub kowalencyjnymi.

Metody niekowalencyjne wiązania czynników są znacznie mniej popularne i rzadziej wykorzystywane ze względu na to, iż są mniej trwałe niż kowalencyjne i szybciej uwalniają wprowadzony do matrycy czynnik. Należy do nich zastosowanie:

- D-fenyloalanylo-prolylo-arginylo-ketonu chlorometylowego (PPACK) (ryc. 3 - II),

- domeny Kringle 4 oraz

- DNA [58, 61, 104].

Niekowalencyjne wiązanie czynników wzrostu można osiągnąć przez ich związanie z PPACK (ryc. 3 - II) lub domeną Kringle 4, mającymi wysokie powinowactwo odpowiednio do TRB lub do plazminogenu i protrombiny, tworzącymi elementy sieci fibrynowej [58, 104]. Przykładowo związanie domeny Kringle 4 z FGF-2 przedłuża jego uwalnianie do 5 dni $[58,104]$. 
Różnoimienne ładunki DNA i fibryny są natomiast odpowiedzialne za powstanie oddziaływań elektrostatycznych. Zjawisko to wykorzystano do niekowalencyjnego związania plazmidu kodującego IL-10 i wydłużenia jego uwalniania in vitro [58].

Częściej stosowanymi metodami wiązania czynników wzrostu do fibryny są metody kowalencyjne, do których należy wykorzystanie:

- 1-etylo-3-(3-dimetyloaminopropylo) karbodiimidu (EDC) (ryc. 3 - III) oraz

- peptydu specyficznego dla FXIIla (NQEQVSPL) (ryc. 3 - IV) [61, 95, 97].

EDC jest znanym aktywatorem grup karboksylowych, warunkując tworzenie nowych wiązań aminowych pomiędzy dwoma aminami pierwszorzędowymi. Tym sposobem czynnik wzrostu można związać do fibryny bezpośrednio lub przez odpowiednie białko, mające powinowactwo do fibryny np. fibronektynę (ryc. 3 - III) [61].

Inną metodą pozwalającą na kowalencyjne związanie czynnika wzrostu polega na dodaniu do niego ogona aminokwasowego o sekwencji NQEQVSPL, który ulega sieciowaniu pod wpływem FXIlla z identycznymi sekwencjami występującymi naturalnie w fibrynie (ryc. 3 - IV i ryc. 4 - I). Późniejsze uwalnianie czynników wzrostu jest związane z degradacją matrycy fibrynowej [70].
Ogon aminokwasowy NQEQVSPL jest podstawą do opracowania bardziej złożonych metod kowalencyjnego łączenia czynników wzrostu z fibryną (ryc. 4). Jedną z nich jest koniugacja ogona NQEQVSPL z HBD, która umożliwia wprowadzenie do struktury fibryny czynnika wzrostu lub heparyny związanej z tym czynnikiem (ryc. 4 - II i III) [12, 95, 97]. Modyfikacja proporcji: NQEQVSPL-HBD : heparyna : czynnik wzrostu, zapewnia regulację szybkości uwalniania czynników wzrostu [45, 95, 97]. Uwalnianie czynników wzrostu, związanych w przedstawiony sposób zachodzi na zasadzie dyfuzji, jednak liczba wolnych czynników wzrostu jest limitowana przez oddziaływania heparyny z fibryną [97].

Konstrukt NQEQVSPL-LIKMKP-czynnik wzrostu jest innym rozwiązaniem pozwalającym na łączenie czynnika wzrostu z fibryną. Sekwencja aminokwasowa LIKMKP jest miejscem specyficznym dla działania plazminy, której działanie tym samym reguluje uwalnianie czynników wzrostu. $W$ ten sposób uwalnianie czynników jest skorelowane z degradacją fibryny przez plazminę (ryc. 4 - IV) [4, 73].

Innym sposobem jest wykorzystanie bifunkcjonalnych cząsteczek PEG do wiązania czynników wzrostu w sieci fibrynowej. Metoda ta opiera się na kowalencyjnym związaniu zarówno fibryny, jak i czynnika wzrostu do zmodyfikowanego PEG. Uwalnianie związanych w ten sposób czynników wzrostu jest uzależnione od degradacji fibryny [19, 103].

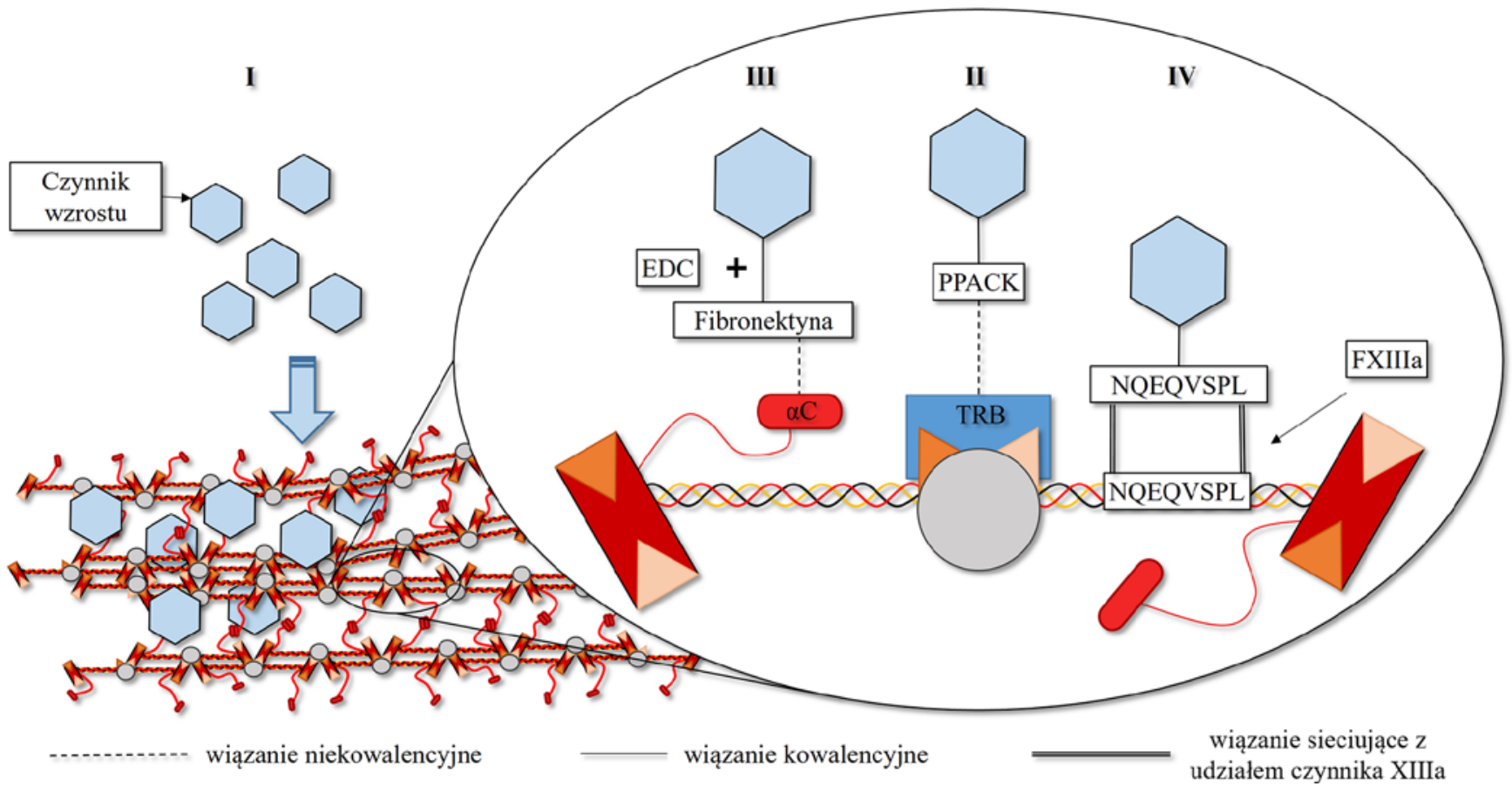

Ryc. 3. Przykłady sposobów inkorporacji czynników wzrostu do fibryny: I - pułapkowanie w matrycy fibrynowej; II - wiązanie z udziałem PPACK; III - wiązanie z udziałem EDC; IV - sieciowanie z udziałem FXIIla. 


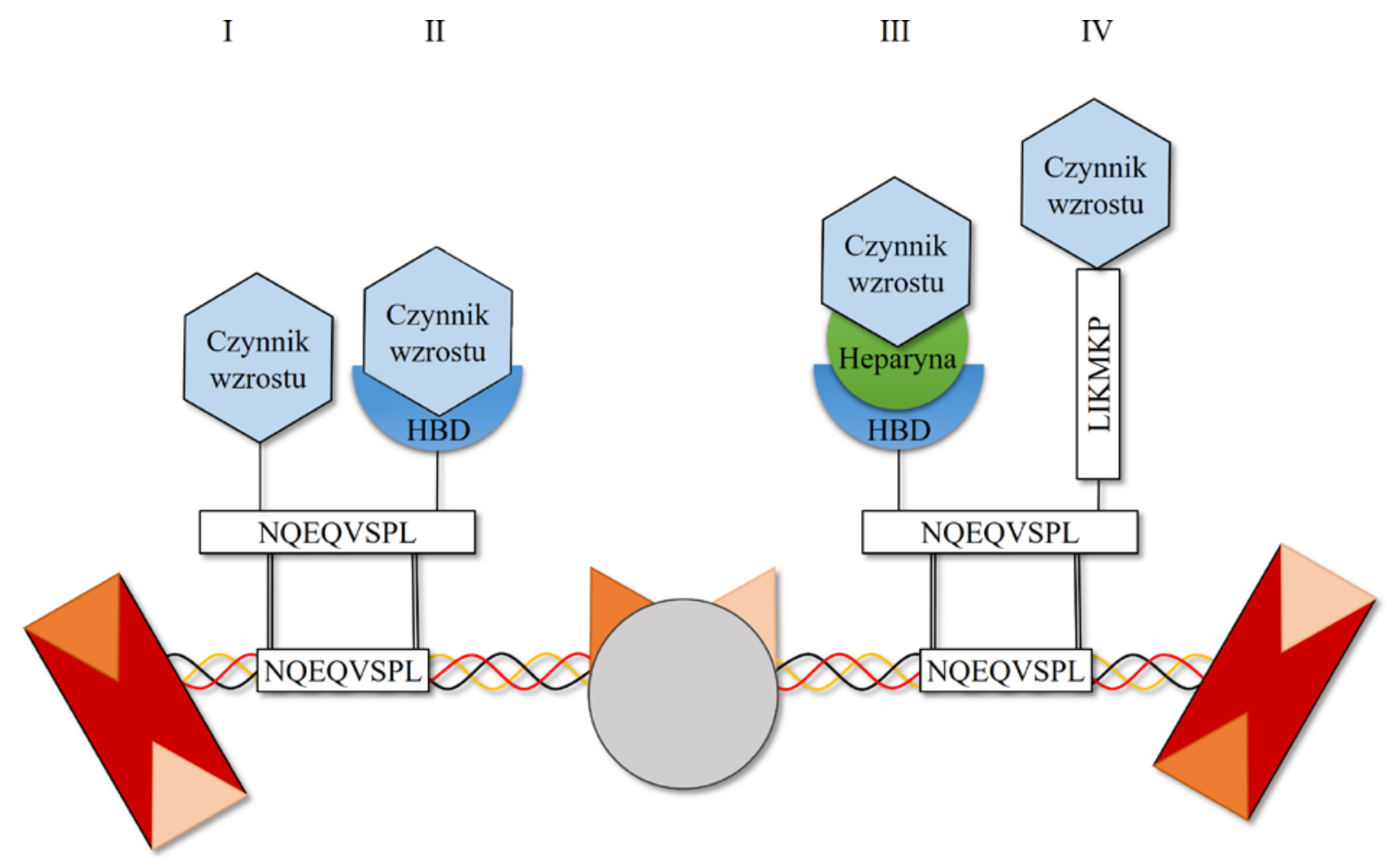

Ryc. 4. Sposoby wiązania czynników wzrostu do fibryny z wykorzystaniem ogona NQEQVSPL: I - bezpośrednio przez ogon NQEQVSPL; II - przez HBD związaną do fibryny ogonem NQEQVSPL; III - przez heparynę związaną do HBD, która jest związana jak w II; IV - przez ogon LIKMPK-NQEQVSPL.

HBD - domena wiążąca heparynę; NQEQVSPL - peptyd specyficzny dla FXIIla, LIKMKP - sekwencja specyficzna hydrolizowana przez plazminę

\section{Regeneracja tkanek z użyciem żelu fibrynowego}

Dane literaturowe informują głównie o proponowanych rozwiązaniach terapeutycznych fibryny oraz w mniejszym stopniu o rozwiązaniach komercyjnych i eksperymentach medycznych w rekonstrukcji tkanki kostnej, nerwowej oraz mięśni poprzecznie prążkowanych [37, 101, 102] (tabela 1). Wśród najczęściej wykorzystanych czynników wzrostu najliczniej występuje białko morfogenetyczne kości (BMP-2), kwaśny czynnik wzrostu fibroblastów (FGF-1), podstawowy czynnik wzrostu fibroblastów (FGF-2), neurotropina 3 (NT-3) i czynnik wzrostu nerwów $\beta$ ( $\beta$ NGF) [37, 101, 102].

Jednym $z$ terapeutycznych zastosowań fibryny jest naprawa uszkodzeń kostnych przez dostarczenie pułapkowanego BMP-2 lub BMP-2 z dołączonym ogonem LIKMPK-NQEQVSPL, również w postaciach nieglikozylowanych (nglBMP-2) i rekombinowanych (rhBMP-2) oraz znacznie rzadziej VEGF i parathormonu. Najczęściej fibrynę w rekonstrukcji tej tkanki wykorzystuje się w postaciach dysków i żelu. Wynika to z prostego sposobu aplikacji oraz możliwości łatwego dopasowania tej formy do uszkodzeń [40, 56, 73, 105].

W terapii uszkodzeń tkanki nerwowej najbardziej popularnymi czynnikami wzrostu dostarczanymi za pomocą fibryny jest $\alpha F G F$, NT-3 oraz $\beta N G F w$ formie rekombinowanej (rhßNGF). Do zwiększenia skuteczności terapeutycznej fibryny zastosowano również odpowiednie peptydy zwiększające adhezję i proliferację komórek [72].

W przypadku terapii mięśni poprzecznie prążkowanych wykorzystano zrębowy czynnik wzrostu 1 (SDF-1) [102].

Dodatkowe wzmocnienie efektów terapeutycznych jest osiągane przez kontrolę czasu uwalniania czynników wzrostu, z których najpopularniejsze to wykorzystanie HBD oraz ogona NQEQVSPL [10, 45, 81, 95, 97].

\section{Perspektywy dla zastosowania fibryny w inżynierii tkankowej}

Fibryna spełnia wiele kryteriów stawianych przed biomateriałami wykorzystywanymi w inżynierii tkankowej. Współczesna wiedza umożliwia kontrolowanie reakcji 
Tabela 1. Przykłady wykorzystania fibryny jako nośnika czynników wzrostu i komórek w inżynierii tkankowej z uwzględnieniem efektów terapeutycznych i modeli badawczych

\begin{tabular}{|c|c|c|c|c|c|c|}
\hline 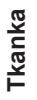 & $\begin{array}{l}\text { Czynnik wzrostu; } \\
\text { Ilość }\end{array}$ & 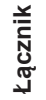 & $\begin{array}{l}\text { Postać; } \\
\text { rozmiar/ilość } \\
\text { fibryny }\end{array}$ & Efekt terapeutyczny & $\begin{array}{l}\text { Model badawczy } \\
\text { in vivo }\end{array}$ & Źródło \\
\hline \multirow{10}{*}{ 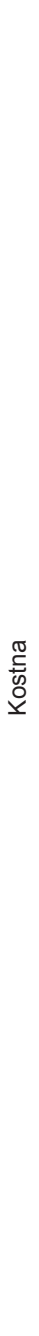 } & $\begin{array}{l}\text { BMP-2; } \\
2 \mu \mathrm{g} / 100 \mu \mathrm{l} \text { fibryny }\end{array}$ & $x$ & $\begin{array}{l}\text { Żel; } \\
300 \mu l\end{array}$ & $\begin{array}{l}\text { Powstanie skupiska kości beleczkowej o wielkości } \\
\qquad 135 \pm 27 \mu \mathrm{l} \text { po } 12 \text { tygodniach. }\end{array}$ & $\begin{array}{l}\text { Szczury Fishera; } \\
\text { myszy pozbawione } \\
\text { grasicy }\end{array}$ & [105] \\
\hline & $\begin{array}{l}\text { VEGF; } \\
600 \mu \mathrm{g} / 30 \mathrm{mg} \text { PLGA }\end{array}$ & $x$ & $\begin{array}{l}\text { Żel z mikrocząstkami } \\
\text { PLGA z VEGF; } \\
2 \text { ml }\end{array}$ & $\begin{array}{l}\text { Rewaskularyzacja i naprawa uszkodzeń kości po } \\
12 \text { tygodniach. Wzrost ilości nowej tkanki kostnej } \\
\text { po } 8 \text { tygodniach. }\end{array}$ & $\begin{array}{l}\text { Psy } \\
\text { Beagle }\end{array}$ & [103] \\
\hline & 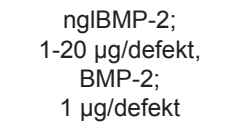 & $x$ & $\begin{array}{l}\text { Dysk; } \\
8 \mathrm{~mm}\end{array}$ & $\begin{array}{l}\text { Naprawa uszkodzenia sklepienia czaszki } \\
\text { po } 3 \text { tygodniach. }\end{array}$ & $\begin{array}{l}\text { Szczury } \\
\text { Sprague-Dawley }\end{array}$ & [73] \\
\hline & $\begin{array}{c}\text { nglBMP-2; } \\
10-40 \mu g / k g \text { m.c. }\end{array}$ & & Żel & $\begin{array}{l}\text { Powstanie tkanki kostnej w nadgarstku } \\
\text { po } 12 \text { tygodniach. }\end{array}$ & Psy & \\
\hline & $\begin{array}{c}\text { FGF-2; } \\
1 \mu \mathrm{g} / \text { defekt }\end{array}$ & $x$ & $\begin{array}{c}\text { Żel; } \\
100 \mu l\end{array}$ & $\begin{array}{l}\text { Powstanie tkanki kostnej i wzrost zawartości wap- } \\
\text { nia we wszczepie podskórnym fałdu grzbietowego. } \\
\text { Neowaskularyzacja, wzrost gęstości arterioli } \\
\text { i ekspresji genów osteogenicznych w implancie po } \\
12 \text { tygodniach. }\end{array}$ & $\begin{array}{l}\text { Szczury } \\
\text { Levis }\end{array}$ & [56] \\
\hline & $\begin{array}{c}\text { BMP-2; } \\
5,15 \mu \mathrm{g} / \mathrm{ml} \text { fibryny }\end{array}$ & \multirow{3}{*}{ 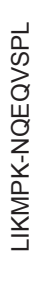 } & $\begin{array}{l}\text { Dysk; } \\
8 \mathrm{~mm}\end{array}$ & $\begin{array}{l}\text { Naprawa uszkodzeń sklepienia czaszki } \\
\text { po } 4 \text { tygodniach. }\end{array}$ & $\begin{array}{l}\text { Króliki } \\
\text { New Zealand }\end{array}$ & \multirow{3}{*}{ [74] } \\
\hline & $\begin{array}{l}\text { BMP-2; } \\
1 \mu \mathrm{g} / \mathrm{defekt}\end{array}$ & & $\begin{array}{l}\text { Dysk; } \\
8 \mathrm{~mm}\end{array}$ & $\begin{array}{c}\text { Naprawa uszkodzeń sklepienia czaszki } \\
\text { po } 3 \text { tygodniach. }\end{array}$ & $\begin{array}{l}\text { Szczury } \\
\text { Sprague-Dawley }\end{array}$ & \\
\hline & $\begin{array}{l}\text { BMP-2; } \\
600 \mu \mathrm{g} / \mathrm{ml} \text { fibryny }\end{array}$ & & $\begin{array}{c}\text { Żel; } \\
0.5-1 \mathrm{ml}\end{array}$ & $\begin{array}{l}\text { Powstanie tkanki kostnej w stawie nadgarstkowym } \\
\text { po } 20 \text { tygodniach. }\end{array}$ & Psy & \\
\hline & $\begin{array}{l}\text { rhBMP-2; } \\
15 \mu \mathrm{g} / \text { defekt }\end{array}$ & $x$ & $\begin{array}{c}\text { Dysk; } \\
6 \mathrm{~mm}, 100 \mu \mathrm{l} \text { objętości }\end{array}$ & $\begin{array}{l}\text { Naprawa uszkodzeń sklepienia czaszki } \\
\text { po } 4 \text { tygodniach. }\end{array}$ & $\begin{array}{l}\text { Króliki } \\
\text { New Zealand }\end{array}$ & [40] \\
\hline & $\begin{array}{l}\text { Parathormon; } \\
1 \mathrm{mg} / \mathrm{ml} \text { fibryny }\end{array}$ & 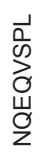 & $\begin{array}{c}\text { Żel; } \\
500 \mu l\end{array}$ & $\begin{array}{c}\text { Powstanie tkanki kostnej w szyjce i nasadzie kości } \\
\text { udowej i ramiennej po } 8 \text { tygodniach. }\end{array}$ & Owce & [4] \\
\hline
\end{tabular}




\begin{tabular}{|c|c|c|c|c|c|c|}
\hline 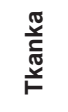 & $\begin{array}{l}\text { Czynnik wzrostu; } \\
\text { llość }\end{array}$ & 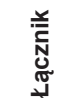 & $\begin{array}{l}\text { Postać; } \\
\text { rozmiar/ilość fibryny }\end{array}$ & Efekt terapeutyczny & $\begin{array}{l}\text { Model badawczy } \\
\quad \text { in vivo }\end{array}$ & Źródło \\
\hline \multirow{4}{*}{ 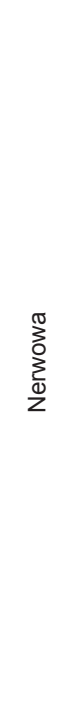 } & $\begin{array}{c}\text { FGF-1; } \\
2.1 \mu \mathrm{g} / \mathrm{ml} \text { fibryny }\end{array}$ & $x$ & $\begin{array}{l}\text { Żel; } \\
10 \mu l\end{array}$ & $\begin{array}{c}\text { Przywrócenie ciągłości oraz funkcji rdzenia } \\
\text { kręgowego (T8), częściowe odzyskanie czucia } \\
\text { w kończynach oraz przywrócenie zdolności chodu } \\
\text { po } 1 \text { roku. }\end{array}$ & $\begin{array}{c}\text { Szczury } \\
\text { Sprague-Dawley }\end{array}$ & [10] \\
\hline & $\begin{array}{l}\text { NT-3; } \\
100 \text { ng/ml fibryny }\end{array}$ & 完 & $\begin{array}{c}\text { Żel; } \\
400 \mu l\end{array}$ & $\begin{array}{l}\text { Zwiększenie gęstości włókien nerwowych } \\
\text { w rdzeniu kręgowym (T9) po } 9 \text { dniach. }\end{array}$ & $\begin{array}{l}\text { Szczury } \\
\text { Long Evans }\end{array}$ & [81] \\
\hline & $\begin{array}{l}\text { peptydy: RGD, IKVAV, } \\
\text { YIGSR, RNIAEIIKDI }\end{array}$ & $\begin{array}{l}\overrightarrow{0} \\
\text { क } \\
\text { ô } \\
\text { 㟧 } \\
z\end{array}$ & $\begin{array}{c}\text { Żel; } \\
400 \mu l\end{array}$ & $\begin{array}{l}\text { Zwiększenie ilości aksonów zmielinowanych } \\
\text { w zwoju korzenia grzbietowego po } 4 \text { tygodniach. }\end{array}$ & $\begin{array}{l}\text { Szczury } \\
\text { Wistar }\end{array}$ & [72] \\
\hline & $\begin{array}{c}\text { rhßNGF; } \\
5,20,50 \mathrm{ng} / \mathrm{ml} \text { fibryny }\end{array}$ & 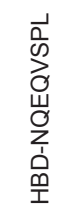 & $\begin{array}{l}\text { Wypełnienie silikonowej } \\
\text { tuby żelem }\end{array}$ & $\begin{array}{l}\text { Naprawa uszkodzonych nerwów kulszowych } \\
\text { i obwodowych po } 6 \text { tygodniach. }\end{array}$ & $\begin{array}{l}\text { Szczury } \\
\text { Wistar }\end{array}$ & [45] \\
\hline 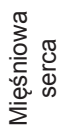 & $\begin{array}{l}\text { SDF-1; } \\
10 \mu \mathrm{g} / \mathrm{ml} \text { fibryny }\end{array}$ & 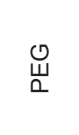 & Żel & $\begin{array}{l}\text { Rekrutacja komórek macierzystych, naprawa usz- } \\
\text { kodzonej tkanki lewej komory serca po } 28 \text { dniach. }\end{array}$ & $\begin{array}{l}\text { Myszy } \\
\text { BALB/c }\end{array}$ & [102] \\
\hline
\end{tabular}

polimeryzacji fibryny w warunkach in vitro, z możliwością modyfikacji jej struktury w celu kontrolowania degradacji i uwalniania czynników wzrostu. Prowadzenie procesu bez rozpuszczalników organicznych i w fizjologicznym zakresie temperatur zapewnia zachowanie biologicznej aktywności czynników wzrostu. Pozwala to na celowe wykorzystanie bioaktywnych właściwości fibryny do odbudowy tkanek, wspomagane czynnikami wzrostu. Dalsze zwiększanie użyteczności fibryny, przez wprowadzanie odpowiednich cząsteczek adhezyjnych oraz możliwość kontrolowanego uwalniania czynników wzrostu i cząsteczek DNA, stwarzają obiecujące możliwości rozwoju nowych terapii [13, 32, 41].

Właściwości fizykochemiczne i reologiczne oraz wykorzystanie metod druku 3D i elektroprzędzenia, umożliwiają formulacje różnych postaci fibryny wraz z dopasowaniem ich kształtu do miejsca uszkodzenia bez utraty bioaktywnych funkcji fibryny. Obecne możliwości druku 3D pozwalają na druk komórek zawieszonych w macierzy fibrynowej, co w niedługim czasie powinno umożliwić druk większych fragmentów funkcjonalnych tkanek, a docelowo całych organów [2, 23]. Wspomniane metody formulacji umożliwiają poprawę właściwości mechanicznych fibryny przez tworzenie biomateriałów, zawierających inny materiał polimerowy, czego przykładem są włókniny fibryny z PLGA
[5]. Powstanie bardziej wytrzymałych materiałów fibrynowych jest niezbędne do przyspieszonej i prawidłowej naprawy uszkodzeń, takich tkanek jak kostna czy też chrzęstna [7, $30,60,62]$. Obecne metody pozyskiwania fibrynogenu są uzależnione od krwi. Rozwój biotechnologicznych metod otrzymywania fibrynogenu umożliwi zmniejszenie kosztów i może się przyczynić do znacznego wzrostu popularności fibryny w niedalekiej przyszłości [36].

\section{Podsumowanie}

Właściwości biostatyczne i bioaktywne fibryny predysponują ją do szerokiego zastosowania w inżynierii tkankowej. Oprócz pełnienia roli rusztowania dla komórek, fibryna inicjuje proces odnowy uszkodzeń, jak również pełni rolę stymulatora komórek. Ponadto jej struktura pozwala na pułapkowanie i wiązanie czynników wzrostu, co stwarza możliwości wykorzystania jej jako systemu ich kontrolowanego uwalniania.

Przeprowadzone eksperymenty lecznicze wskazują, że podłoża fibrynowe uwalniające czynniki wzrostu umożliwiają zwiększenie skuteczności terapeutycznej naprawy tkanek. 
W najbliższej dekadzie wyroby medyczne otrzymywane za pomocą druku 3D i elektroprzędzenia mogą zwiększyć efektywność terapeutyczną, dzięki dopasowaniu materiału do uszkodzenia tkanek i synergistycznego wykorzystania bioaktywnych właściwości fibryny z czynnikami wzrostu do odbudowy tkanek.

Praca powstała dzięki wsparciu finansowemu SUM, nr umowy: KNW-1-040/N/9/O

\section{Wykaz skrótów}

a i b - dołki w domenie D fibrynogenu; A i B - węzły w domenie E fibrynogenu; BMP - białko morfogenetyczne kości; D - domena dystalna fibrynogenu; E - domena centralna fibrynogenu; ECM - macierz zewnątrzkomórkowa; EDC - 1-etylo-3-(3-dimetyloaminopropylo) karbodiimid; FBN - fibrynogen; fbpA i fbpB - fibrynopeptydy A i B; FGF - czynnik wzrostu fibroblastów; FXIlla - aktywna postać czynnika XIII kaskady krzepnięcia krwi; HBD - domena wiążąca heparynę; IGFBP - białka wiążące insulinopodobne czynniki wzrostu; nglBMP-2 - nieglikozylowane białko morfogenetyczne kości 2; NT - neurotropina; PDGF płytkowe czynniki wzrostu; PEG - poli(tlenek etylenu); PIGF - łożyskowe czynniki wzrostu; PLGA - poli(laktydko-glikolid); PPACK - D-fenyloalanylo-prolylo-arginyloketon chlorometylowy; rhBMP-2 - rekombinowany morfogenetyczny czynnik wzrostu kości 2; rh $\beta N G F$ - $\beta$ NGF w formie rekombinowanej; SDF-1 - zrębowy czynnik wzrostu 1; TGF- $\boldsymbol{\beta}$ - czynniki wzrostu guzów $\beta$; TRB - trombina; VEGF - czynniki wzrostu śródbłonka naczyń; $\alpha, \beta, \mathbf{Y}-$ łańcuchy aminokwasowe łączące domeny $E$ i $D$ fibrynogenu; $\alpha C$ - domena $\alpha C$ fibrynogenu; $\beta$ NGF - czynnik wzrostu nerwów $\beta$.

\section{Piśmiennictwo}

[1] Ahmad E., Fatima M.T., Hoque M., Owais M., Saleemuddin M.: Fibrin matrices: The versatile therapeutic delivery systems. Int. J. Biol. Macromol., 2015; 81: 121-136

[2] Ahn J., Kim S.A., Kim K.W., Oh J.H., Kim S.J.: Optimization of TGF- $\beta 1$-transduced chondrocytes for cartilage regeneration in a 3D printed knee joint model. PLoS One, 2019; 14: e0217601

[3] Akpalo E., Bidault L., Boissière M., Vancaeyzeele C., Fichet O., Garde V.: Fibrin-polyethylene oxide interpenetrating polymer networks: new self-supported biomaterials combining the properties of both protein gel and synthetic polymer. Acta Biomater., 2011; 7 : 2418-2427

[4] Arrighi I., Mark S., Alvisi M., von Rechenberg B., Hubbell J.A., Schense J.C.: Bone healing induced by local delivery of an en- gineered parathyroid hormone prodrug. Biomaterials, 2009; 30: 1763-1771

[5] Bacakova M., Musilkova J., Riedel T., Stranska D., Brynda E., Bacakova L., Zaloudkova M.: The potential applications of fibrincoated electrospun polylactide nanofibers in skin tissue engineering. Int. J. Nanomedicine, 2016; 11: 771-789

[6] Brown A.C., Barker T.H.: Fibrin-based biomaterials: modulation of macroscopic properties through rational design at the molecular level. Acta Biomater., 2014; 10: 1502-1514

[7] Bujoli B., Scimeca J.: Fibrin as a multipurpose physiological platform for bone tissue engineering and targeted delivery of bioactive compounds. Pharmaceutics, 2019; 11: 1-15

[8] Cha D.M., Kim K.H., Choi H.J., Kim M.K., Wee W.R.: A comparative study of the effect of fibrin glue versus sutures on clinical outcome in patients undergoing pterygium excision and conjunctival autografts. Korean J. Ophthalmol., 2012; 26: 407-413

[9] Chen Z., Wang L., Stegemann J.P.: Phase-separated chitosanfibrin microbeads for cell delivery. J. Microencapsul., 2011; 28 : 344-352

[10] Cheng H., Cao Y., Olson L.: Spinal cord repair in adult paraplegic rats: partial restoration of hind limb function. Science, 1996; 273 510-513

[11] Cholewinski E., Dietrich M., Flanagan T.C., Schmitz-Rode T., Jockenhoevel S.: Tranexamic acid-an alternative to aprotinin in fibrin-based cardiovascular tissue engineering. Tissue Eng. Part A, 2009; 15: 3645-3653

[12] Christman K.L., Vardanian A.J., Fang Q., Sievers R.E., Fok H.H., Lee R.J.: Injectable fibrin scaffold improves cell transplant survival, reduces infarct expansion, and induces neovasculature formation in ischemic myocardium. J. Am. Coll. Cardiol., 2004; 44: 654-660

[13] Ciardulli M.C., Marino L., Lovecchio J., Giordano E., Forsyth N.R., Selleri C., Ma N., Porta G.: Tendon and cytokine marker expression by human bone marrow mesenchymal stem cells in a hyaluronate/poly-lactic-co-glycolic acid (PLGA)/fibrin three-dimensional (3D) scaffold. Cells, 2020; 9: 1268

[14] Collen A., Smorenburg S., Peters E., Lupu F., Koolwijk P., van Noorden C., van Hinsbergh V.: Unfractionated and low molecular weight heparin affect fibrin structure and angiogenesis in vitro. Cancer Res., 2000; 60: 6196-6200

[15] De Cristofaro R., de Candia E.: Thrombin domains: structure, function and interaction with platelet receptors. J. Thromb. Thrombolysis, 2003; 15: 151-163

[16] Cui X., Boland T.: Human microvasculature fabrication using thermal inkjet printing technology. Biomaterials, 2009; 30: 6221-6227

[17] Cwalina B., Turek A., Nozynski J., Jastrzebska M., Nawrat Z.: Structural changes in pericardium tissue modified with tannic acid. Int. J. Artif. Organs, 2005; 28: 648-653

[18] Dietrich M., Heselhaus J., Wozniak J., Weinandy S., Mela P., Tschoeke B., Schmitz-Rode T., Jockenhoevel S.: Fibrin-based tissue engineering: comparison of different methods of autologous fibrinogen isolation. Tissue Eng. Part C Methods, 2013; 19: 216226 
[19] Drinnan C.T., Zhang G., Alexander M.A., Pulido A.S., Suggs L.J.: Multimodal release of transforming growth factor- $\beta 1$ and the $B B$ isoform of platelet derived growth factor from PEGylated fibrin gels. J. Control. Release, 2010; 147: 180-186

[20] Ehrbar M., Metters A., Zammaretti P., Hubbell J.A., Zisch A.H.: Endothelial cell proliferation and progenitor maturation by fibrinbound VEGF variants with differential susceptibilities to local cellular activity. J. Control. Release, 2005; 101: 93-109

[21] Esposito F., Angileri F.F., Kruse P., Cavallo L.M., Solari D., Esposito V., Tomasello F., Cappabianca P.: Fibrin sealants in dura sealing: a systematic literature review. PLoS One, 2016; 11: e0151533

[22] Ferguson J., Nürnberger S., Redl H.: Fibrin: the very first biomimetic glue - still a great tool. W: Biological adhesive systems, red.: J. von Byern, I. Grunwald. Springer Vienna, 2010, 225-236

[23] Freeman S., Ramos R., Chando P.A., Zhou L.: A bioink blend for rotary $3 \mathrm{D}$ bioprinting tissue engineered small-diameter vascular constructs. Acta Biomater., 2019; 5: 152-164

[24] Frey R.: Fibrin sealants. http://www.surgeryencyclopedia.com/ Ce-Fi/Fibrin-Sealants.html (06.10.2016)

[25] Gandossi E., Lunven C., Berry C.N.: Role of clot-associated (-derived) thrombin in cell proliferation induced by fibrin clots in vitro. Br. J. Pharmacol., 2000; 129: 1021-1027

[26] Gorkun O.V., Veklich Y.I., Medved L.V., Henschen A.H., Weisel J.W.: Role of the .alpha.c domains of fibrin in clot formation. Biochemistry, 1994; 33: 6986-6997

[27] Goszczyński T., Nevozhay D., Wietrzyk J., Omar M.S., Boratyński J.: The antileukemic activity of modified fibrinogen-methotrexate conjugate. Biochim. Biophys. Acta - Gen. Subj., 2013; 1830: 25262530

[28] Gray A., Reeves J., Harrison N., Winlove P., Laurent G.: Growth factors for human fibroblasts in the solute remaining after clot formation. J. Cell. Sci., 1990; 96: 271-274

[29] Gugerell A., Schossleitner K., Wolbank S., Nürnberger S., Redl H., Gulle H., Goppelt A., Bittner M., Pasteiner W.: High thrombin concentrations in fibrin sealants induce apoptosis in human keratinocytes. J. Biomed. Mater. Res. Part A, 2012; 100A: 1239-1247

[30] Gupta N., Cruz M., Nasser P., Rosenberg J., latridis J.: Fibringenipin hydrogel for cartilage tissue engineering in nasal reconstruction. Ann. Otol. Rhinol. Laryngol., 2019; 128: 640-646

[31] Harvey S.C.: Fibrin paper as an hæmostatic agent. Ann. Surg., 1918; 68: 66-70

[32] Heher P., Mühleder S., Mittermayr R., Redl H., Slezak P.: Fibrinbased delivery strategies for acute and chronic wound healing. Adv. Drug Deliv. Rev., 2018; 129: 134-147

[33] Highlights of prescribing information. https://advancedsurgery. baxter.com/products/tisseel (07.07.2020).

[34] Hino M., Ishiko O., Honda K., Yamane T., Ohta K., Takubo T., Tatsumi N.: Transmission of symptomatic parvovirus B19 infection by fibrin sealant used during surgery. Br. J. Haematol., 2000; 108: 194-195

[35] Hinton T.J., Jallerat Q., Palchesko R.N., Park J.H., Grodzicki M.S., Shue H.-J., Ramadan M.H., Hudson A.R., Feinberg A.W.:
Three-dimensional printing of complex biological structures by freeform reversible embedding of suspended hydrogels. Sci. Adv., 2015; 1: e1500758

[36] Hirashima M., Imamura T., Yano K., Kawamura R., Meta A., Tokieda Y., Nakashima T.: High-level expression and preparation of recombinant human fibrinogen as biopharmaceuticals. J. Biochem., 2016; 159: 261-270

[37] Hojo M., Inokuchi S., Kidokoro M., Fukuyama N., Tanaka E., Tsuji C., Miyasaka M., Tanino R., Nakazawa H.: Induction of vascular endothelial growth factor by fibrin as a dermal substrate for cultured skin substitute. Plast. Reconstr. Surg., 2003; 111: 1638-1646

[38] Jennewein C., Tran N., Paulus P., Ellinghaus P., Eble J.A., Zacharowski K.: Novel aspects of fibrin(ogen) fragments during inflammation. Mol. Med., 2011; 17: 568-573

[39] Joch C.: The safety of fibrin sealants. Cardiovasc. Surg., 2003; 11: $23-28$

[40] Jung R.E., Schmoekel H.G., Zwahlen R., Kokovic V., Hammerle C.H.F., Weber F.E.: Platelet-rich plasma and fibrin as delivery systems for recombinant human bone morphogenetic protein-2. Clin. Oral Implants Res., 2005; 16: 676-682

[41] Kaiser N.J., Kant R.J., Minor A.J., Coulombe K.L.K.: Optimizing blended collagen-fibrin hydrogels for cardiac tissue engineering with human iPSC-derived cardiomyocytes. ACS Biomater. Sci. Eng., 2019; 5: 887-899

[42] Kang S.W., Kim J.S., Park K.S., Cha B.H., Shim J.H., Kim J.Y., Cho D.W., Rhie J.W., Lee S.H.: Surface modification with fibrin/hyaluronic acid hydrogel on solid-free form-based scaffolds followed by BMP-2 loading to enhance bone regeneration. Bone, 2011; 48: 298-306

[43] Kawamura M., Sawafuji M., Watanabe M., Horinouchi H., Kobayashi K.: Frequency of transmission of human parvovirus B19 infection by fibrin sealant used during thoracic surgery. Ann. Thorac. Surg., 2002; 73: 1098-1100

[44] Kay A., Pepper D., Ewart M.: Generation of chemotactic activity for leukocytes by the action of thrombin on human fibrinogen. Nat. New Biol., 1973; 243: 56-57

[45] Lee A.C., Yu V.M., Lowe J.B., Brenner M.J., Hunter D.A., Mackinnon S.E., Sakiyama-Elbert S.E.: Controlled release of nerve growth factor enhances sciatic nerve regeneration. Exp. Neurol., 2003; 184: 295-303

[46] Lee J.H., Kang N.Y.: Comparison of fibrin glue and sutures for conjunctival wound closure in strabismus surgery. Korean J. Ophthalmol., 2011; 25: 178-184

[47] Lesman A., Koffler J., Atlas R., Blinder Y.J., Kam Z., Levenberg S.: Engineering vessel-like networks within multicellular fibrinbased constructs. Biomaterials, 2011; 32: 7856-7869

[48] Li Y., Meng H., Liu Y., Lee B.P.: Fibrin gel as an injectable biodegradable scaffold and cell carrier for tissue engineering. Sci. World J., 2015; 2015: 1-10

[49] Lieshout M. Van, Peters G., Rutten M., Baaijens F.: A knitted, fibrin-covered polycaprolactone scaffold for tissue engineering of the aortic valve. Tissue Eng., 2006; 12: 481-487 
[50] Lishko V.K., Podolnikova N.P., Yakubenko V.P., Yakovlev S., Medved L., Yadav S.P., Ugarova T.P.: Multiple binding sites in fibrinogen for integrin aMß2 (Mac-1). J. Biol. Chem., 2004; 279: 44897-44906

[51] Litvinov R.I., Weisel J.W.: Fibrin mechanical properties and their structural origins. Matrix Biol., 2017; 60-61: 110-123

[52] Lorand L.: Factor XIII: structure and interactions with fibrinogen and fibrin. Ann. N. Y. Acad. Sci., 2006; 936: 291-311

[53] Malafaya P.B., Silva G.A., Reis R.L.: Natural-origin polymers as carriers and scaffolds for biomolecules and cell delivery in tissue engineering applications. Adv. Drug Deliv. Rev., 2007; 59: 207233

[54] Mankad P.S., Codispoti M.: The role of fibrin sealants in hemostasis. Am. J. Surg., 2001; 182: S21-S28

[55] Martino M.M., Briquez P.S., Ranga A., Lutolf M.P., Hubbell J.A.: Heparin-binding domain of fibrin(ogen) binds growth factors and promotes tissue repair when incorporated within a synthetic matrix. Proc. Natl. Acad. Sci., 2013; 110: 4563-4568

[56] Min Sun P., Sang-Soo K., Seung-Woo C., Cha Yong C., ByungSoo K.: Enhancement of the osteogenic efficacy of osteoblast transplantation by the sustained delivery of basic fibroblast growth factor. J. Biomed. Mater. Res. Part B Appl. Biomater., 2006; 79B: 353-359

[57] Mittermayr R., Morton T., Hofmann M., Helgerson S., van Griensven M., Redl H.: Sustained (rh)VEGF 165 release from a sprayed fibrin biomatrix induces angiogenesis, up-regulation of endogenous VEGF-R2, and reduces ischemic flap necrosis. Wound Repair Regen., 2008; 16: 542-550

[58] Morton T.J., Fürst W., Griensven M. van, Redl H.: Controlled release of substances bound to fibrin-anchors or of DNA. Drug Deliv., 2009; 16: 102-107

[59] Narayanan S.: Multifunctional roles of thrombin. Ann. Clin. Lab. Sci., 1999; 29: 275-280

[60] Noori A., Ashrafi S., Vaez-Ghaemi R., Hatamian-Zaremi A., Webster T.: A review of fibrin and fibrin composites for bone tissue engineering. Int. J. Nanomedicine, 2019; 12: 4937-4961

[61] Osathanon T., Giachelli C.M., Somerman M.J.: Immobilization of alkaline phosphatase on microporous nanofibrous fibrin scaffolds for bone tissue engineering. Biomaterials, 2009; 30: 4513-4521

[62] Park C., Woo K.: Fibrin-based biomaterial applications in tissue engineering and regenerative medicine. Adv. Exp. Med. Biol., 2018; 1064: 253-261

[63] Peyvandi F.: Epidemiology and treatment of congenital fibrinogen deficiency. Thromb. Res., 2012; 130: S7-S11

[64] Rahmany M.B., Hantgan R.R., van Dyke M.: A mechanistic investigation of the effect of keratin-based hemostatic agents on coagulation. Biomaterials, 2013; 34: 2492-2500

[65] Ramanathan A., Karuri N.: Fibronectin alters the rate of formation and structure of the fibrin matrix. Biochem. Biophys. Res. Commun., 2014; 443: 395-399

[66] Rao R.R., Peterson A.W., Ceccarelli J., Putnam A.J., Stegemann J.P.: Matrix composition regulates three-dimensional network for- mation by endothelial cells and mesenchymal stem cells in collagen/fibrin materials. Angiogenesis, 2012; 15: 253-264

[67] Rech J., Wilińska J., Borecka A., Turek A.: Application of fibrin in drug technology: Achievements and perspectives. Postepy Hig. Med. Dosw., 2020; 74: 322-330

[68] Richardson D.L., Pepper D.S., Kay A.B.: Chemotaxis for human monocytes by fibrinogen-derived peptides. Br. J. Haematol., 1976; 32: $507-514$

[69] Robson S.C., Shephard E.G., Kirsch R.E.: Fibrin degradation product $\mathrm{D}$-dimer induces the synthesis and release of biologically active IL-1 $\beta$, IL- 6 and plasminogen activator inhibitors from monocytes in vitro. Br. J. Haematol., 1994; 86: 322-326

[70] Sacchi V., Mittermayr R., Hartinger J., Martino M.M., Lorentz K.M., Wolbank S., Hofmann A., Largo R.A., Marschall J.S., Groppa E., Gianni-Barrera R., Ehrbar M., Hubbell J.A., Redl H., Banfi A.: Long-lasting fibrin matrices ensure stable and functional angiogenesis by highly tunable, sustained delivery of recombinant VEGF164. Proc. Natl. Acad. Sci., 2014; 111: 6952-6957

[71] Sang-Hyug P., So Ra P., Soo II C., Ki Soo P., Byoung-Hyun M.: Tissue-engineered cartilage using fibrin/hyaluronan composite gel and its in vivo implantation. Artif. Organs, 2005; 29: 838-845

[72] Schense J.C., Bloch J., Aebischer P., Hubbell J.A.: Enzymatic incorporation of bioactive peptides into fibrin matrices enhances neurite extension. Nat. Biotechnol., 2000; 18: 415-419

[73] Schmoekel H., Schense J.C., Weber F.E., Grätz K.W., Gnägi D., Müller R., Hubbell J.A.: Bone healing in the rat and dog with nonglycosylated BMP-2 demonstrating low solubility in fibrin matrices. J. Orthop. Res., 2004; 22: 376-381

[74] Schmoekel H.G., Weber F.E., Schense J.C., Grätz K.W., Schawalder P., Hubbell J.A.: Bone repair with a form of BMP-2 engineered for incorporation into fibrin cell ingrowth matrices. Biotechnol. Bioeng., 2005; 89: 253-262

[75] Senior R.M., Skogen W.F., Griffin G.L., Wilner G.D.: Effects of fibrinogen derivatives upon the inflammatory response. Studies with human fibrinopeptide B. J. Clin. Invest., 1986; 77: 1014-1019

[76] Sierra D.H.: Fibrin sealant adhesive systems: a review of their chemistry, material properties and clinical applications. J. Biomater. Appl., 1993; 7: 309-352

[77] Smadja D.M., Basire A., Amelot A., Conte A., Bièche I., Le Bonniec B.F., Aiach M., Gaussem P.: Thrombin bound to a fibrin clot confers angiogenic and haemostatic properties on endothelial progenitor cells. J. Cell. Mol. Med., 2008; 12: 975-986

[78] Spicer P.P., Mikos A.G.: Fibrin glue as a drug delivery system. J. Control. Release, 2010; 148: 49-55

[79] Spotnitz W.D.: Fibrin sealant: the only approved hemostat, sealant, and adhesive-a laboratory and clinical perspective. ISRN Surg., 2014; 2014: 1-28

[80] Sreerekha P.R., Menon D., Nair S. V., Chennazhi K.P.: Fabrication of fibrin based electrospun multiscale composite scaffold for tissue engineering applications. J. Biomed. Nanotechnol., 2013; 9: $790-800$ 
[81] Taylor S.J., Rosenzweig E.S., McDonald J.W., Sakiyama-Elbert S.E.: Delivery of neurotrophin-3 from fibrin enhances neuronal fiber sprouting after spinal cord injury. J. Control. Release, 2006; 113: $226-235$

[82] Thompson W.D., Smith E.B., Stirk C.M., Marshall F.I., Stout A.J., Kocchar A.: Angiogenic activity of fibrin degradation products is located in fibrin fragment E. J. Pathol., 1992; 168: 47-53

[83] Tidrick R.T., Warner E.D.: Fibrin fixation of skin transplants. Surgery, 1944; 15: 90-95

[84] Turek A., Stoklosa K., Borecka A., Paul-Samojedny M., Kaczmarczyk B., Marcinkowski A., Kasperczyk J.: Designing biodegradable wafers based on poly(L-lactide-co-glycolide) and poly(glycolideco- $\varepsilon$-caprolactone) for the prolonged and local release of idarubicin for the therapy of glioblastoma multiforme. Pharm. Res., 2020; 37: 90

[85] Turek A., Cwalina B., Kobielarz M.: Radioisotopic investigation of crosslinking density in bovine pericardium used as a biomaterial. Nukleonika, 2013; 58: 511-517

[86] Turek A., Wilińska J., Borecka A., Pawlus-Łachecka L.: Application of antibiotics in the sterilization of homogeneic heart valves. Postepy Hig. Med. Dosw., 2017; 71: 1187-1201

[87] VeraSeal: EPAR - Product Information. https://www.ema.europa. eu/en/medicines/human/EPAR/veraseal-0\#product-informationsection (07.07.2020)

[88] Verma K., Errico T.J., Vaz K.M., Lonner B.S.: A prospective, randomized, double-blinded single-site control study comparing blood loss prevention of tranexamic acid (TXA) to epsilon aminocaproic acid (EACA) for corrective spinal surgery. BMC Surg., 2010; 10: 13

[89] Voge C.M., Johns J., Raghavan M., Morris M.D., Stegemann J.P.: Wrapping and dispersion of multiwalled carbon nanotubes improves electrical conductivity of protein-nanotube composite biomaterials. J. Biomed. Mater. Res. Part A, 2013; 101A: 231-238

[90] Wang X., Sui S., Yan Y., Zhang R.: Design and fabrication of PLGA sandwiched cell/fibrin constructs for complex organ regeneration. J. Bioact. Compat. Polym., 2010; 25: 229-240

[91] Wardrop D., Estcourt L.J., Brunskill S.J., Doree C., Trivella M., Stanworth S., Murphy M.F.: Antifibrinolytics (lysine analogues) for the prevention of bleeding in patients with haematological disorders. Cochrane Database Syst. Rev., 2016; 3: CD009733

[92] Weisel J.W., Litvinov R.I.: Fibrin formation, structure and properties. Subcell Biochem., 2017; 82: 405-456

[93] Weisel J.W., Medved L.: The structure and function of the $\alpha C$ domains of fibrinogen. Ann. N. Y. Acad. Sci., 2006; 936: 312-327
[94] Wilińska J., Turek A., Borecka A., Rech J., Kasperczyk J.: Electron beam sterilization of implantable rods with risperidone and with 17- $\beta$-estradiol: A structural, thermal and morphology study. Acta Bioeng. Biomech., 2019; 21: 39-47

[95] Willerth S.M., Rader A., Sakiyama-Elbert S.E.: The effect of controlled growth factor delivery on embryonic stem cell differentiation inside fibrin scaffolds. Stem Cell Res., 2008; 1: 205-218

[96] Wnek G.E., Carr M.E., Simpson D.G., Bowlin G.L.: Electrospinning of nanofiber fibrinogen structures. Nano Lett., 2003; 3: 213216

[97] Wood M.D., Borschel G.H., Sakiyama-Elbert S.E.: Controlled release of glial-derived neurotrophic factor from fibrin matrices containing an affinity-based delivery system. J. Biomed. Mater. Res. Part A, 2009; 89A: 909-918

[98] Wysocka A., Mann K., Bursig H., Dec J., Gaździk T.S.: Chondrocyte suspension in fibrin glue. Cell Tissue Bank., 2010; 11: 209215

[99] Xu M., Wang X., Yan Y., Yao R., Ge Y.: An cell-assembly derived physiological $3 \mathrm{D}$ model of the metabolic syndrome, based on adipose-derived stromal cells and a gelatin/alginate/fibrinogen matrix. Biomaterials, 2010; 31: 3868-3877

[100] Xu W., Wang X., Yan Y., Zheng W., Xiong Z., Lin F., Wu R., Zhang R.: Rapid prototyping three-dimensional cell/gelatin/fibrinogen constructs for medical regeneration. J. Bioact. Compat. Polym., 2007; 22: 363-377

[101] Ye Q., Zünd G., Benedikt P., Jockenhoevel S., Hoerstrup S.P., Sakyama S., Hubbell J.A., Turina M.: Fibrin gel as a three dimensional matrix in cardiovascular tissue engineering. Eur. J. CardioThoracic Surg., 2000; 17: 587-591

[102] Zhang G., Nakamura Y., Wang X., Hu Q., Suggs L.J., Zhang J.: Controlled release of stromal cell-derived factor-1alpha in situ increases C-kit + cell homing to the infarcted heart. Tissue Eng., 2007; 13: 2063-2071

[103] Zhang L., Zhang L., Lan X., Xu M., Mao Z., Lv H., Yao Q., Tang $P .:$ Improvement in angiogenesis and osteogenesis with modified cannulated screws combined with VEGF/PLGA/fibrin glue in femoral neck fractures. J. Mater. Sci. Mater. Med., 2014; 25: 1165-1172

[104] Zhao W., Han Q., Lin H., Sun W., Gao Y., Zhao Y., Wang B., Wang X., Chen B., Xiao Z., Dai J.: Human basic fibroblast growth factor fused with Kringle4 peptide binds to a fibrin scaffold and enhances angiogenesis. Tissue Eng. Part A, 2009; 15: 991-998

[105] Zhu S.-J., Choi B.-H., Jung J.-H., Lee S.-H., Huh J.-Y., You T.M., Lee H.-J., Li J.: A comparative histologic analysis of tissueengineered bone using platelet-rich plasma and platelet-enriched fibrin glue. Oral Surg. Oral Med. Oral Pathol. Oral Radiol. Endod., 2006; 102: 175-179 